\title{
Hepatic and splenic cytotoxic evaluation after Crataegus oxyacantha fruit extract administration on mice
}

\begin{abstract}
Jéssica Cristina dos Santos ${ }^{1}$, Patrícia Rosa de Oliveira², Maria Izabel Camargo-Mathias², Fábio Ferreira Perazzo ${ }^{3}$, Paulo Cesar Pires Rosa 4 , Isabel O’Neill de Mascarenhas Gaivão ${ }^{5}$ and Edson Luis Maistro ${ }^{1,6^{*}}$
\end{abstract}

*Correspondence: edson.maistro@unesp.br

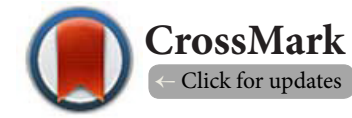

\begin{abstract}
'São Paulo State University - UNESP - Instituto de Biociências, Programa de Pós-Graduação em Biologia Geral e Aplicada, Botucatu, SP, Brazil.

2Universidade Estadual Paulista Julio de Mesquita Filho - UNESP - Instituto de Biociências, Departamento de Biologia, Rio Claro, SP, Brazil. ${ }^{3}$ Universidade Federal de São Paulo - UNIFESP, Departamento de Ciências Exatas e da Terra, Diadema, SP, Brazil.

${ }^{4}$ Universidade Estadual de Campinas - UNICAMP, Faculdade de Ciências Médicas, Campinas, SP, Brazil.

${ }^{5}$ University of Trás-os-Montes and Alto Douro, CECAV and Department of Genetics and Biotechnology, Vila Real, Portugal.

${ }^{6}$ São Paulo State University- UNESP - Faculty of Phylosophy and Sciences, Speech and Hearing Therapy Department, Marília, SP, Brazil.
\end{abstract}

\begin{abstract}
The plant Crataegus oxyacantha L., Rosaceae, also known as white hawthorn or hawthorn, is originally native to Europe, North America and Asia, but can also be found in other continents and has been widely used due to its potential pharmacological effects, such as cardiotonic, anti-oxidant, hypolipidemic, antiinflammatory, sedative, among others. Considering the importance of C. oxyacantha as a natural alternative medicine, and the lack of studies involving its cellular toxicity, the objective of this study was to analyze the morpho-histological effects of $C$. oxyacantha fruit extract in the liver and spleen cells of mice supplemented with 50 (I), 100 (II) or200 $\mathrm{mg} / \mathrm{kg}$ (III) of extract, in order to evaluate its cytotoxic effects. The liver of the individuals in group I showed no damage. Individuals in group II presented liver in the early stages of tissue and cytoplasmic disorganization. Those of group III suffered major histological alterations such as extensive cytoplasmic disorganization, appearance of vacuoles and increased sinusoidal capillaries, and large amounts of Kupffer cells. On the other hand, the spleen was not histologically modified after the treatments, maintaining its architecture as in the control group. Histochemical analyzes revealed alteration in the liver only, both in the amount of polysaccharides and lipids. It can be concluded that supplementation with $C$. oxyacantha fruit extract in higher doses leads to tissue disorganization in the liver of mice that indicates the need for caution with continuous and/or high doses use of this plant.
\end{abstract}

Keywords: Hawthorn cytotoxicity, Hawthorn liver toxicity, Rosaceae toxicology, Hawthorn liver disorganization

\section{Introduction}

The use of medicinal plants for therapeutic purposes is one of the oldest practices performed by humans considering their many biological and pharmacological properties [1]. Their use in the population ranges from 70 to $95 \%$ according to the World Health Organization, and according to Tomazzoni et al. [2] this fact may be related to the high cost of industrialized drugs, lack of access to medical and pharmaceutical care, and tendency to use products of vegetable origin. The major concern is the toxicity of herbal medicines, because even though they are natural, they can trigger several adverse reactions due to interaction with other drugs and foods [3].

Crataegus is a genus of plant belonging to the family Rosaceae, native in Europe, North America and West Asia, but is also found in other continents, such as South America. It is popularly known as white hawthorn or hawthorn, which refers to the numerous thorns found in the plant and its white flowers [4] which, in the spring, create large clusters and, in the autumn, turn into small globular bright red fruits with one to three seeds in the interior [5]. The plant has been used mainly to treat cardiovascular disorders, but has other properties such as hypolipidemic, anti-oxidant, anti-inflammatory, digestive 
and sedative activity [6]. Its fruits have long been used as a diuretic for dyspnea and kidney stones. There are also studies that show its sedative and anxiolytic effects [7].

The liver is one of the largest organs of vertebrates, which receives a large amount of blood through the portal vein $(75 \%$ of all blood passing thought the liver), carrying all venous blood drained from the digestive tract, spleen and pancreas, and receives a smaller amount (the remaining $25 \%$ ) of blood (arterial blood) from the hepatic arteries [8]. Moreover, due to its location and metabolization function, it is one of the first organs showing the impacts of toxic compounds [9].

The spleenis involved in all systemic inflammations and, under stress conditions, may present lymphocytic cell depletion, congestion and reticuloendothelial cell necrosis $[10,11]$. In this way, the histopathological study of the spleen can act as a biomarker of environmental impact since the splenic alterations can be directly associated to the health status of these animals [12].

Considering the potential of $C$. oxyacantha as a natural alternative medicine for humans, and the lack of studies focusing the cytotoxicity of its extracts, the present study aimed at analysingthe histological and histochemical data of liver and spleen cells of mice exposed to different doses of a C. oxyacantha fruit extract.

\section{Materials and methods \\ Animals}

Thirty 12-week-old male Swiss albino mice (Mus musculus) were used, weighing between $25-30 \mathrm{~g}$ (6 specimens per treatment group).

The specimens were obtained from the bioterium of the São Paulo State University (UNESP), Botucatu, state of São Paulo, Brazil, in controlled climate $\left(25 \pm 4^{\circ} \mathrm{C}, 55 \pm 5 \%\right.$ moisture) with $12 \mathrm{~h}$ light/dark cycle (7:00 a.m. to 7:00 p.m.). The mice were identified individually and within the treatment groups. Each group was kept inpolyethylene boxes, with food (Nuvilab CR1, Nuvital) and water available ad libitum.

The study was approved by the Animal Bioethics Committee of the Medical School of Marília (CEP/FAMEMA, Marília, state of São Paulo, Brazil), protocol number 1661/12, according to federal legislation on animal care.

\section{Preparation and characterization of the Crataegus oxyacantha extract}

Crataegus oxyacantha fruits were harvested in Turkey and acquired by a certified distributor in Brazil. A sample voucher was sent to the laboratory of Phytotropics of the University of Alfenas, UNIFENAS, Minas Gerais, Brazil, with the number LFF00297. Fresh fruits of $C$. oxyacantha were dried and extracted with $70 \%$ methanolat room temperature. The macerate was filtered and concentrated under reduced pressure, using a rotary evaporator, resulting in a crude methanolic extract. For chemical determination, the extract was analyzed using liquid chromatography linked to a mass detector. The chro- matographic conditions used were: C18 column ( $100 \times 2.1$ $\mathrm{mm}, 1.7$ million $\mathrm{m}^{3}$, temperature of $30^{\circ} \mathrm{C}$, with an injection volume of $2 \mathrm{~mL}$ [13].

\section{Experimental groups and doses of Crataegus oxyacan- tha extract}

The doses of $C$. oxyacantha extract selected for this work were based on the effective anti-inflammatory doses [14]. C. oxyacantha extract was dissolved in distilled water and administered to mice at a volume of $0.3 \mathrm{~mL}$, per oral gavage, for seven consecutive days and with an interval of $24 \mathrm{~h}$, at doses of 50 (group I), 100 (group II) and 200 (group III) mg/ $\mathrm{kg}$ mouse body weight. At these doses the animals showed no signs of toxicity, such as locomotor alterations, diarrhea or piloerection. A control group of mice was also considered, administered with $0.3 \mathrm{~mL}$ of distilled water (oral gavage) in the same time period.

\section{Histology}

The mice were sacrificed after 7 days of treatment with the extract, by cervical displacement without anesthesia, then, these animals were placed on wax plates to be dissected. The excess tissue was removed with the aid of scissors and dissection tweezers. Fractions of the livers (right lobes) and baits were separated from the animals and deposited in phosphate buffered saline, then fixed for $24 \mathrm{~h}$ in paraform aldehyde at $4 \%$, and transferred to a sodium phosphate buffer solution for another $24 \mathrm{~h}$. Afterwards, they were dehydrated in a growing series of ethanol, incorporated in resin for $24 \mathrm{~h}$ and transferred to plastic molds previously filled with polymerized resin. After polymerization of the resin, all the blocks were sectioned in slices with $3 \mu \mathrm{m}$ of thickness and collected in glass slides for staining with hematoxylin and eosin. The slides obtained were examined and analyzed under Olympus BX-50 light microscope.

\section{Histochemistry}

In order to detect histochemical alterations in the liver, such as the presence orabsence, the frequency and distribution of protein, polysaccharide and lipid components, the histological sections were submitted to the following histochemical techniques:

PAS technique for polysaccharide detection [15]: The liver and spleen samples were fixed in aqueous Bouin for five days. The slides containing the sections were rehydrated for $1 \mathrm{~min}$ in distilled water and transferred to $4 \%$ periodic acid solution for $10 \mathrm{~min}$. Soon after they were washed and immersed in the Schiff reagent for $1 \mathrm{~h}$. After this step, the sections were washed for 30 min in running water, dried at room temperature and mounted in Canada balsam.

Bromophenol blue technique for total protein detection [16]: The slides were stained with bromophenol blue solution for $2 \mathrm{~h}$ at room temperature. After being washed with acetic acid at $0.5 \%$ for $5 \mathrm{~min}$, and with running water for $15 \mathrm{~min}$, 
slides quickly passed through tertiary butyl alcohol solution. Next, they were dried outdoors, diaphanized and mounted in Canada balsam.

Baker's technique for lipid detection [17]: The fractions of the livers and spleens were fixed in formol-calcium for $15 \mathrm{~h}$. For this histochemical test, the slides containing the sections were treated for $18 \mathrm{~h}$ with calcium bichromate. After washing in distilled water, they remained in a hemathein solution for $5 \mathrm{~h}$. Soon afterwards, the last washing with distilled water was performed. After drying, the slides were assembled with glycerin and covered with a cover slip.

Nile blue technique for lipid detection [18]: The fractions of the livers and spleens were fixed in formol-calcium for 15 h. For this histochemical test, all liver and spleen slides were stained with Nile blue for $10 \mathrm{~min}$ at $37^{\circ} \mathrm{C}$. After washing with distilled water, the sample was submersed in $1 \%$ acetic acid for $1 \mathrm{~min}$. Then, the slides were washed again. After drying, the slides were assembled with glycerin and covered with a cover slip.

\section{Results}

\section{Liver histology}

Control group -The livers of the animals in the control group presented similar results to the ones described in the literature, polygonal hepatocytes forming anastomosed plaques (Figures $1 \mathrm{~A}$ and 1B). Each hepatocyte contained one or two rounded nuclei, strongly stained by hematoxylin and located in the central region. The presence of one or two nucleoli, as well as a little acidophilus cytoplasm, was also observed. Among the plaques of hepatocytes, sinusoid capillaries were found (Figures 1A and 1B). The capillaries wall was coated by Kupffer cells, observed on light microscopy, mainly by their elongated or triangular and strongly stained nuclei (Figures $\mathbf{1 A}$ and $1 \mathrm{~B}$ ).

Group I (50mg/ $\mathrm{kg})$-The liver of the animals in group I, which were treated with $50 \mathrm{mg} / \mathrm{kg}$ of the C. oxyacantha extract, did not present histological alterations in comparison to those of the control group. Hepatocytes, sinusoid capillaries and Kupffer cells displayed the same characteristics (Figures 1C and 1D).

Group II $(100 \mathrm{mg} / \mathrm{kg})$-The individuals in group II, treated with $100 \mathrm{mg} / \mathrm{kg}$ of the extract, showed the initial stages of tissue and cytoplasmic disorganization in the liver (Figure 1E-1J). The alterations were characterized by the presence of hepatocytes with a more acidophilus cytoplasm, enlarged sinusoid capillaries and mainly by the large increase in the number of Kupffer cells (Figure 1E-1 J).

Group III (200mg/kg)-The animals treated with $200 \mathrm{mg} / \mathrm{kg}$ of the extract (group III) showed higher histological alterations in comparison with the control group, showing extensive tissue disorganization (Figures 2A-2E). Kupffer cells remained in large quantities as in group II, recognized by their flattened and strongly stained nuclei, located between the hepatic plaques (Figures 2A-2E), including hypertrophides (larger than those of the previous groups), suggesting that they were active (Figure 2A-2E). As for the sinusoid capillaries, the
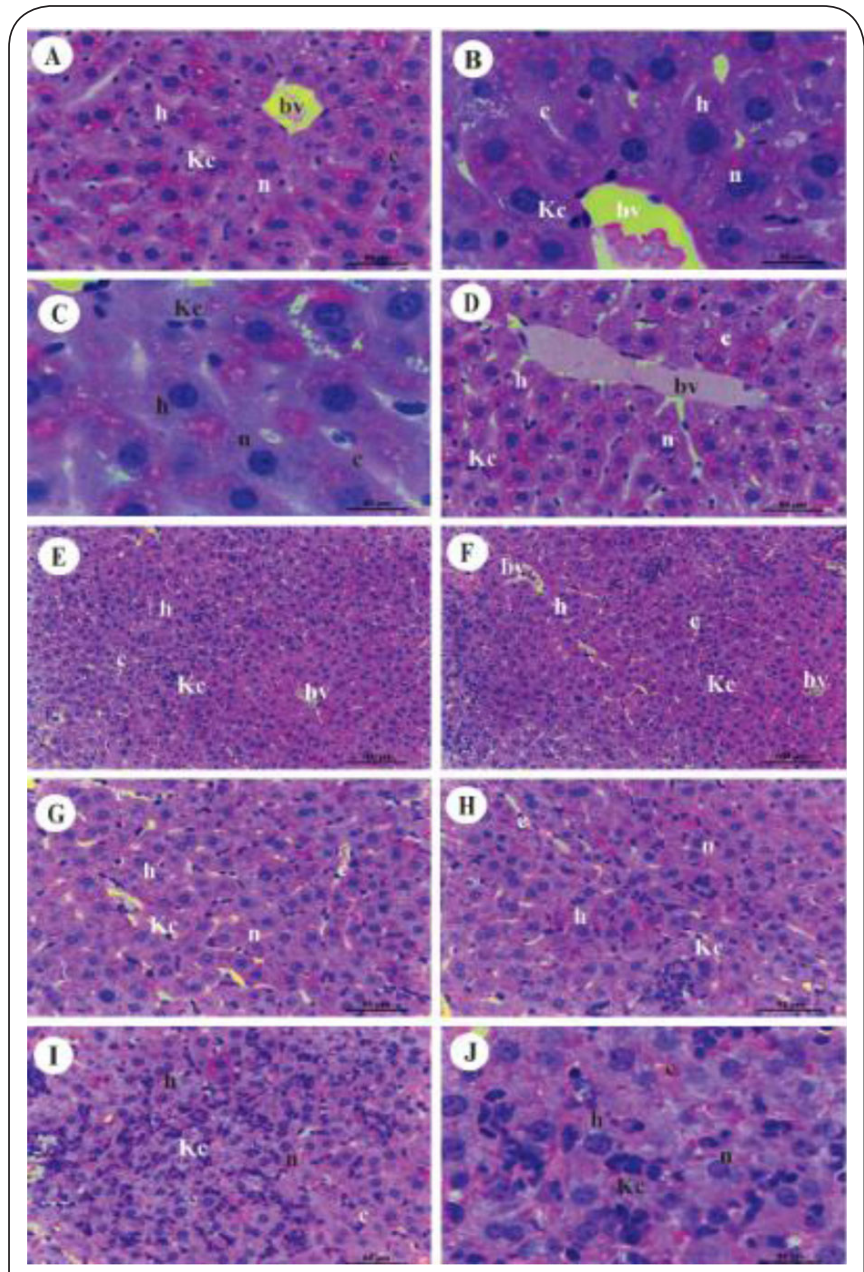

Figure 1. Histological sections of mouse liver treated with Crataegus oxyacantha extract. Caption: A-J. hematoxylin and eosin (HE) stain. A-B. Control group, C-D. Group I (50 mg/ $\mathrm{kg})$, E-J. Group II (100

$\mathrm{mg} / \mathrm{kg}$ ) (c=blood capillaries, h=hepatocytes, Kc=Kupffer cells, $\mathrm{n}=$ hepatocyte nuclei, $\mathrm{bv}=$ blood vessels). All sections had a

thickness of $3 \mu \mathrm{m}$.

light of these vessels was wide and showed large amounts of erythrocytes (Figure 2A-2E).

\section{Liver histochemistry}

Detection of neutral polysaccharides - PAS technique -The application of PAS revealed the presence of polysaccharides in the liver of the control group individuals (Figures 2F-2G), demonstrated by a positive coarse granulation distributed throughout the cytoplasm of the hepatocytes, but with a certain preference for the regions of peripheral nuclei (Figures 2F-2G). The lumen of the sinusoid capillaries and large blood vessels did not react or reacted weakly to the test (Figures $\mathbf{2 F - 2 G}$ ). The liver of the individuals in group I presented the same response as those of the control group (Figures $2 \mathrm{~F}-2 \mathrm{H}$ ). For group II, the polysaccharide marking was less intense when compared to those of the control group, presenting a weakly positive 
and homogeneous reaction throughout the organ (Figure $2 \mathrm{~J}$ and Figure $3 \mathrm{~A}$ ). The liver of the individuals in group III reacted strongly in the central regions, while the peripheral regions of the organ reacted moderately, that is, less intensely as it approaches the most peripheral regions of the liver (Figures 3B-3D).

Protein detection - Bromophenol blue technique-The bromophenol blue technique detected the presence of a large amount of proteins in all regions of the liver in the control group (Figure 3E), which is evident by the strong positive reaction of the cytoplasm, the nucleus of both hepatocytes and the Kupffer cells, as well as the light of the sinusoid capillaries. The liver of the individuals treated with $50 \mathrm{mg} / \mathrm{kg}, 100 \mathrm{mg} / \mathrm{kg}$ and $200 \mathrm{mg} /$ $\mathrm{kg}$ of the extract displayed strong positive reactions, as in the control group, due to the large amount of proteins. In group III, even with the detection of histological alterations, such

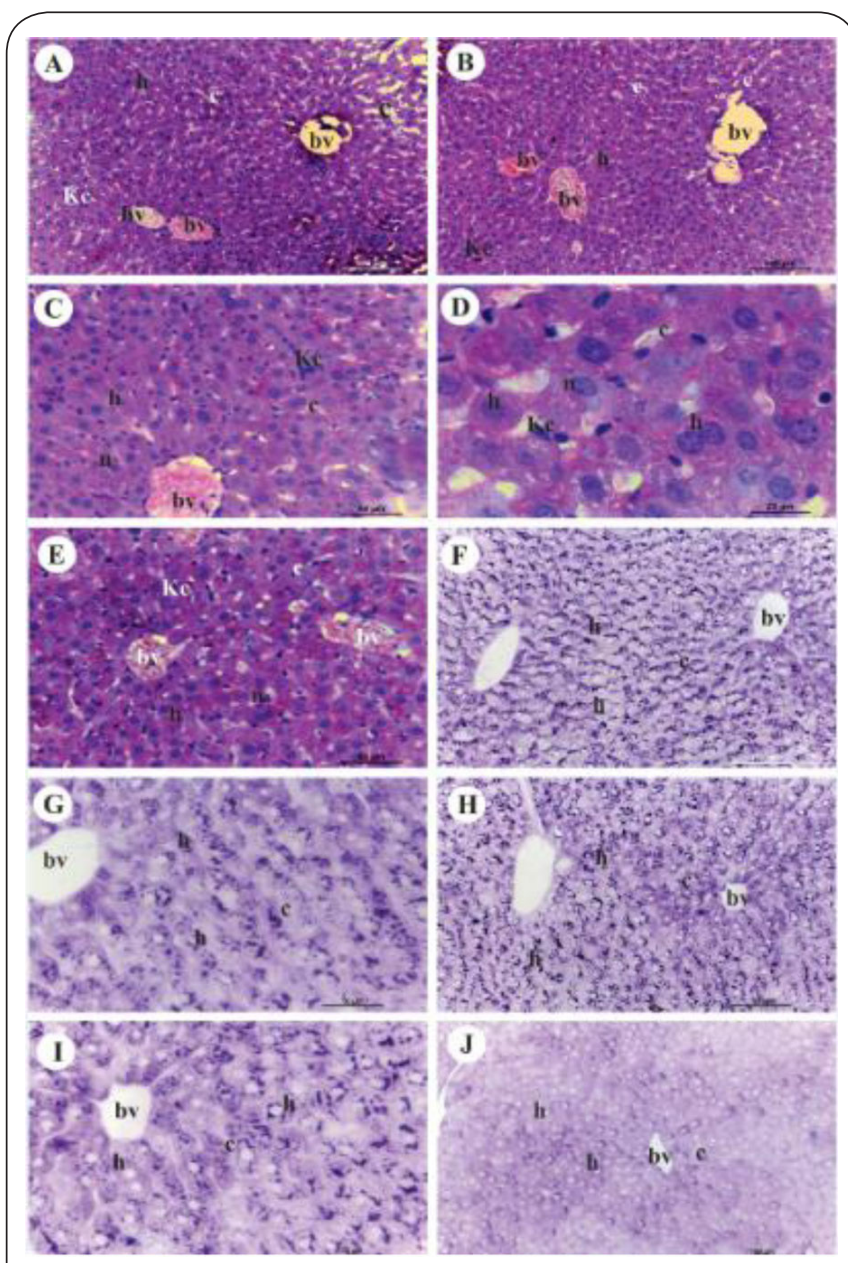

Figure 2. Histological sections of mouse liver treated with the Crataegus oxyacantha extract. Caption: A-E. hematoxylin and eosin (HE) stain, Group III (200 mg/kg). F-J. PAS test for polysaccharide detection.

F-G. Control group, H-I. Group I (50 mg/kg), J. Group II (100 $\mathrm{mg} / \mathrm{kg}$ ) (c=blood capillaries, $\mathrm{h}=$ hepatocytes, Kc=Kupffer cells, $\mathrm{n}=$ hepatocyte nuclei, bv=blood vessels). All sections had a thickness of $3 \mu \mathrm{m}$.

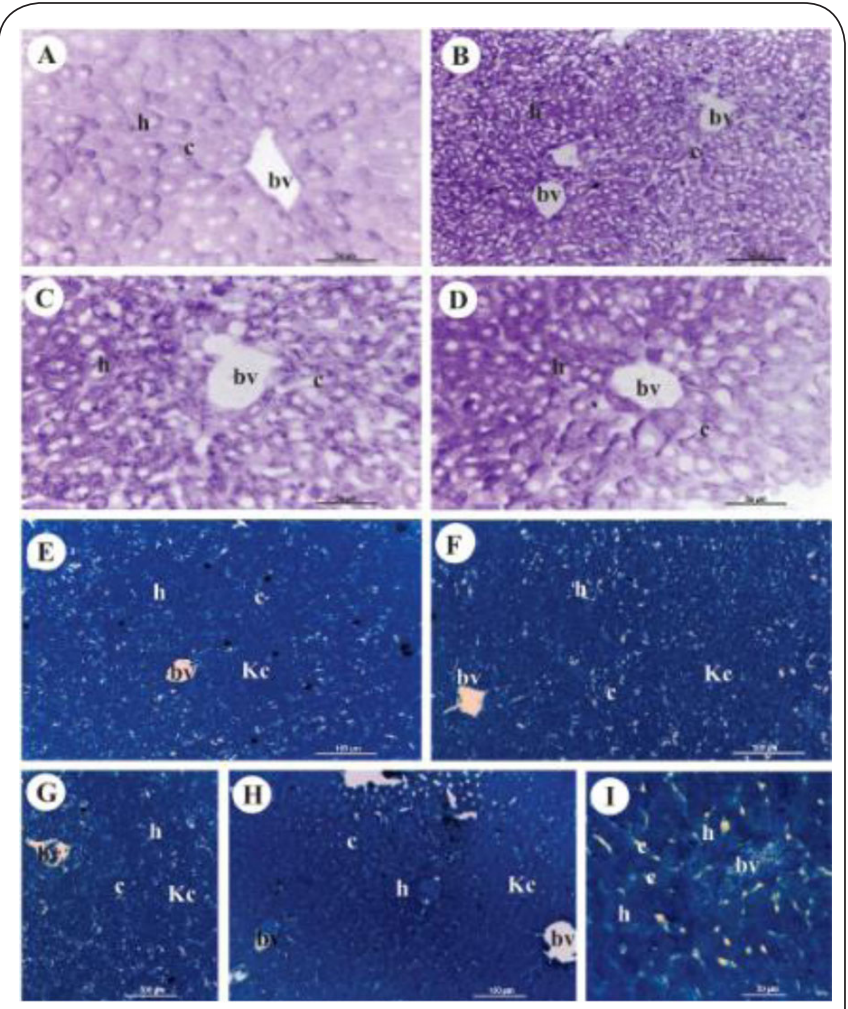

Figure 3. Histological sections of mouse liver treated with Crataegus oxyacantha extract. Caption: A-D. PAS test for polysaccharide detection. A. Group II (100 mg/kg), B-D. Group III (200 mg/kg), E-I Bromophenol blue test for protein detection. E. Control group, F. Group I (50 mg/kg), G. Group II (100 mg/kg), H-I. Group III (200 mg/kg) (c=blood capillaries, h=hepatocytes, Kc=Kupffer cells; bv=blood vessels). All sections had a thickness of $3 \mu \mathrm{m}$.

as the increase of Kupffer cells, there were no reductions in the amount of proteins (Figures 3F-3I).

Lipid detection - Baker's technique -With the application of the Baker's technique, the presence of lipids was observed in the livers of the control group animals. The nuclei of all cells, including those of hepatocytes and Kupffer cells, as well as the nucleoli (hepatocytes), were stained due to the use of hemathein, a solution obtained through the counter-coloration with hematoxylin (Figure 4A). The liver of the individuals in groups I and II showed the same positive reactions the one found in the individuals of the control group (Figures 4B and 4C). Group III livers reacted strongly to the test, indicating the increase of lipid components in the cells and hepatic tissues when compared to those of the previous groups (Figures 4D and 4E). In the cytoplasm of the hepatocytes of group III, there were also vacuoles that reacted negatively to the test (Figures 4D and 4E).

Lipid detection - Nile blue technique-The application of this technique showed the presence of lipids in the liver (positive reaction of the hepatic parenchyma) of the individuals of the control group (Figure 4F). The nuclei of all cells, including those of hepatocytes and Kupffer cells, were stained due to rapid 
counter-coloration with hematoxylin (Figure 4F). The liver of the individuals in group I and II presented a similar reaction to that found in the control group (Figures $\mathbf{4 G}$ and $\mathbf{4 H}$ ). The liver of the individuals in group III presented a more intense lipid marking, although there were vacuoles that reacted negatively to the test (Figures $4 \mathrm{I}$ and $4 \mathrm{~J}$ ).

\section{Spleen histology}

Control group -The spleens of the individuals in the control group were involved by a capsule of dense connective tissue, which sent trabeculae to the interior of the organ, as described in the literature. It presented two distinct regions: the white pulp and the red pulp (Figures 5A and 5B).The white pulp has the splenic nodules, traversed by small blood vessels (central arterioles) (Figures 5A and 5B). The red pulp is found between the splenic nodules and has splenic cords separated

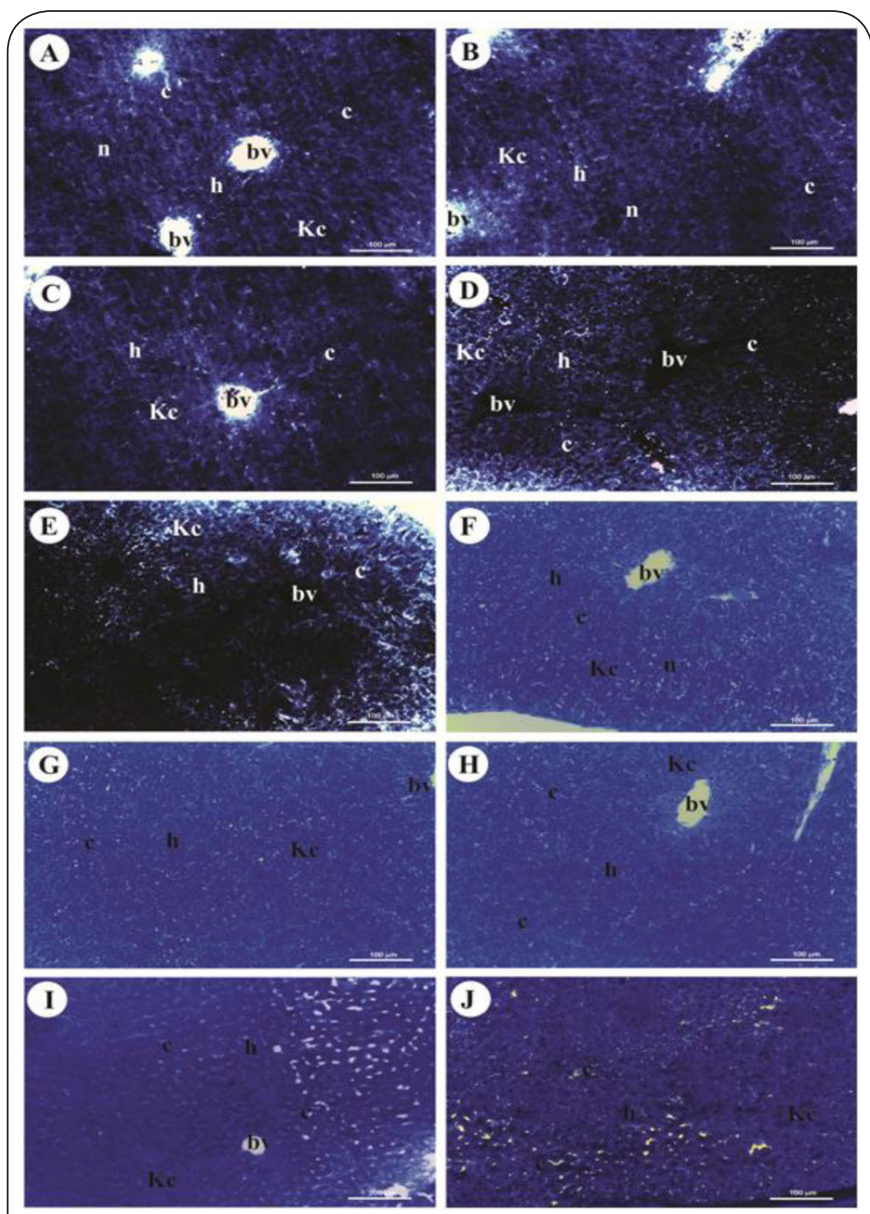

Figure 4. Histological sections of mouse liver treated with Crataegus oxyacantha extract. Caption: A-E. Baker stain for lipid detection. A. Control group, B. Group I (50 mg/kg), C. Group II (100 mg/kg), D-E. Group III (200 mg/kg). F-J. Nile stain for lipid detection. F. Control group, G. Group I (50 mg/kg), H. Group II (100 mg/kg), I-J. Group III (200 mg/ $\mathrm{kg}$ ) ( $\mathrm{c}=$ blood capillaries, $\mathrm{h}=$ hepatocytes, Kc=Kupffer cells, $\mathrm{n}=$ hepatocyte nuclei; bv=blood vessels). All sections had a thickness of $3 \mu \mathrm{m}$. by blood vessels (splenic sinusoids) (Figures 5A and 5B).

The splenic cords presented varied cell nuclei, including erythrocytes (Figures 5A and 5B). The blood vessels (splenic sinusoids) contained erythrocytes and well-evident nuclei of leukocytes in their interior (Figures 5A and 5B).

Groups I (50mg/kg); II (100 $\mathrm{mg} / \mathrm{kg}) ;$ III (200mg/kg) -The spleen of the individuals exposed to the different concentrations of the C. Oxyacantha extract did not show any alterations, remaining intact after the treatments (Figures $5 \mathrm{C}-5 \mathrm{H}$ ). Thus, the architecture of the organ remained similar to that of the control group (Figures 5A-5H).

\section{Spleen histochemistry}

Detection of neutral polysaccharides-PAS technique -The spleen
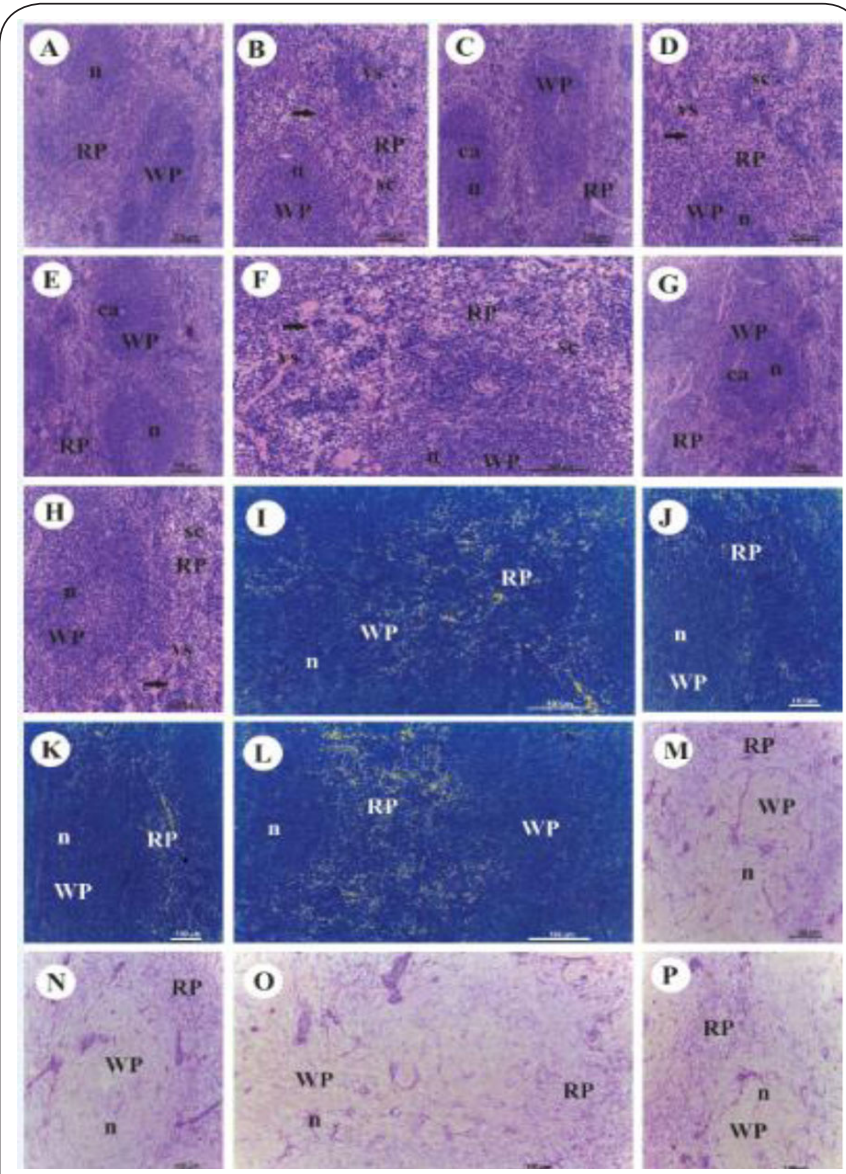

Figure 5. Histological sections of mouse spleen treated with Crataegus oxyacantha extract. Caption: A-H. Hematoxylin and eosin (HE) stain. A-B. Control group, C-D. Group I (50 mg/kg), E-F. Group II (100 mg/kg), G-H. Group III (200 $\mathrm{mg} / \mathrm{kg}$ ). I-L. Bromophenol blue test for protein detection. I. Control group, J. Group I (50 mg/kg), K. Group II (100 mg/ $\mathrm{kg})$, L. Group III (200 mg/kg). M-P. PAS test for polysaccharide detection. M. Control group, N. Group I (50 mg/kg), O. Group II (100 mg/kg), P. Group III (200 mg/kg) (ca=central arteriole; $\mathrm{n}=$ splenic nodule, $\mathrm{RP}=$ red pulp; $\mathrm{sc}=$ splenic cords; $\mathrm{vs}=$ blood vessels; $\mathrm{WP}=$ white pulp, arrow=leucocytes). All sections had a thickness of $3 \mu \mathrm{m}$. 
of the control group individuals showed a weak positive reaction in both the white pulp and in most of the red pulp, demonstrating the presence of a small number of polysaccharides (Figure 5M). However, in the red pulp, it is possible to observe a moderately positive PAS reaction in the blood vessels (splenic sinusoids) and strong positive granulation in the splenic cords (Figure 5M). In the spleen of the individuals in the treatment groups, neither histochemical nor morphological alterations were detected (Figures 5M-5P). The affinity for the PAS reaction is the same as that found in the spleen of the individuals in the control group. Thus, it is noted that the treatment did not alter the number of polysaccharides in the spleen of the treated individuals (Figures 5M-5P).

Protein detection-Bromophenol blue technique -The application of this histochemical test detected the presence of proteins in all regions of the spleen of the control group individuals (Figure 5I). The white pulp presented a weak to moderate reaction (Figure 5I). In the red pulp, the blood vessels (splenic sinusoids), both the wall and the lumen containing the defense cells and erythrocytes, showed a moderately positive reaction (Figure 5I). The splenic cords showed a strong positive reaction, and also presented strongly positive erythrocytes among the strongly positive nuclei of the other cells (Figure 5I). The spleen of the individuals in the treatment groups displayed a similar reaction to those found in the spleen of the control group mice, indicating that the treatment with the C. oxyacantha extract did not alter the protein constitution of the spleen (Figures 5I-5L). A similar reaction was detected throughout the organ parenchyma (Figures 5I-5L).

\section{Discussion}

C.oxyacantha is an example of a plant that is widely used in several countries due to its medicinal potential. Its extracts, which can be crafted from leaves, flowers and fruits, are known for presenting a wide variety of pharmacological effects.

In this study, we used an extract of $C$. oxyacantha fruits, whose chemical evaluation revealed the presence of $2.7 \%$ of flavonoids, with vitexin-4-O-ramnoid (1.79\%) being the major compound present [13]. In another study, conducted by Lakshmi and collaborators [19], the presence of these compounds was $3.54 \%$. The quantity and type of phenolic compounds may vary due to external factors such as local, climate, light and hereditary factors [20].

The histological results obtained for the control group of this study are similar to the ones of the literature - hepatocytes of the same size, with the presence of one or two central nuclei, displaying extensive anastomosed plaques, separated by the sinusoid capillaries; and acidophilic cytoplasm [21-23].

In the treated mice, there was progressive damage caused by the $C$. oxyacantha extract at $100 \mathrm{mg} / \mathrm{kg}$ (group II). The main alterations detected were the initial stages of tissue disorganization and the presence of hepatocytes with more acidophilic cytoplasm. These alterations may be occurring in order to filter the blood containing foreign substances more efficiently and/or to allow the arrival of a larger amount of erythrocytes/leukocytes to participate in the metabolization of these substances [23].

In groups II and III, mice exposure to 100 and $200 \mathrm{mg} / \mathrm{kg}$ of extract, respectively, there was also a large increase in the number of Kupffer cells (macrophages responsible for phagocytosis), probably to eliminate remnants of cells that were damaged after the treatment of individuals with the extracts $[\mathbf{2 2}, \mathbf{2 4 , 2 5}]$. In this way, we can note the attempt to remove extraneous substances from the blood circulation, avoiding the injury to the organism.

The greatest histological alterations were found, specifically, in the liver of the individuals exposed to $200 \mathrm{mg} / \mathrm{kg}$ (group III), indicating that the highest dose of the extract is the one that causes the greatest damage (dose-dependent). These alterations include the emergence of small vacuoles in the liver cells. Similar results were also found by Oliveira et al. [26] and Lora et al. [27] in mice treated with an ethanolic extract of Morus alba (Moraceae) and with an hydroalcoholic extract of Eugenia uniflora leaves, respectively.

In Salam et al. [28], anextract of C. oxyacantha showed the protection against the carbon tetrachloride-induced hepatic damage in rats. The positive control of this study presented severe hepatic injury marked by a complete disorganization of the organ architecture. The treatment groups that were exposed to the extract at 10, 20 and $40 \mathrm{mg} / \mathrm{kg}$ showed a remarkable reduction in liver tissue damage, decreasing fibrosis and vascular degeneration. In those who received the highest doses, histological alterations of the liver were also detected. Thus, both studies highlight the importance of the correct use of plants, i.e., dose standardization and correct treatment.

After the application of the histochemical PAS test, a positive coarse granulation was detected, with a certain preference for peripheral regions of the nuclei in the control group individuals. The polysaccharides detected were, probably, glucose originated from the food that was absorbed by the liver and stored in the hepatocytes in the form of glycogen [29].

The treatment group I did not suffer any histochemical alterations. In group II, a lower intensity of polysaccharide marking was found and, in group III, strong to weak marking (weaker in the most peripheral regions) was visible. This situation may be occurring due to excessive glycogen breakage.

After the application of the bromophenol blue histochemical test, a high amount of proteins in the cytoplasm, in the nuclei and in the light of the sinusoid capillaries were observed. As for treatment groups I, II and III, they presented the same positivity found in the control group individuals, that is, strong positivity due to the large marking of proteins. This data allows us to infer that the protein synthesis performed by the hepatic cell was not affected by the treatment, so the liver of the treated individuals was still able to perform its activities. Similar results were obtained by Oliveira et al. [30] and by Roma et al. [31] in mice. 
The liver also plays a key role in lipid metabolism, transforming fats into fatty acids and glycerol, to synthesize lipoproteins such as $\mathrm{HDL}$, VLDL and LDL, molecules responsible for transporting cholesterol in the blood [23]. In the present study, Baker's and Nile blue techniques were used for lipid detection. The livers of the individuals in the control group showed moderate lipid marking. Group I and II continued to present the same positivity as control individuals. However, group III exhibited strong positivity, revealing the increase of the number of lipid elements in the liver cells and tissues of the individuals treated with the extract at $200 \mathrm{mg} / \mathrm{kg}$, suggesting that there is an imbalance in the synthesis, use or lipid mobilization. In other studies, conducted by Oliveira et al. [30] and by Roma et al. [31], the quantity of lipids also increased in the liver of mice exposed to toxic agents.

Many chemical substances when used inadequately, in addition to causing alterations in certain organs, can also influence the immune system, so it is important to evaluate its effects not only on detoxifying systems (liver), but also in the immunologic (spleen) [32]. The spleen is the largest lymphatic organ and the only lymphoid organ interposed in the bloodstream, so it is able to directly filter the blood. Because of its high number in phagocytic cells and the establishment of an intimate contact between the blood and these cells, the spleen represents an important defense organ against microorganisms that penetrate the circulating blood. Like the other lymphatic organs, it gives rise to lymphocytes that pass into the circulating blood. Because of its location in the bloodstream, the spleen responds very quickly to the antigens that invade the blood, being a phagocytic and immunological filter, as well as a large producer of antibodies $[23,33]$.

According to the data described in the literature and verified in the individuals of the control group of the present study, the spleen is covered by a capsule of connective tissue from which trabeculae extend to the splenic pulp of the organ. The splenic pulp is divided into two regions: the white pulp and the red pulp. The white pulp is formed by the lymphatic tissue, mainly by splenic nodules, and the red one by the splenic cords interspersed by blood vessels [23].

The spleens from the individuals of the treatment groups (I, II and III) were not modified, appearing similar to the spleens of the control group individuals, which indicate that none of the $C$. oxyacantha extract concentrations tested was damaging to the spleen.

These data allows us to suggest that the red and white pulps of the spleen, upon exposure to the different concentration of the extract, continue to performantigen presentation, activation and proliferation of $B$ and $T$ lymphocytes, antibody production and removal of useless blood materials [22,34-36]. Similar results were described by Doi et al. [32] in rats exposed to cyclophosphamide, where the white pulp of the spleen was not altered. The same authors also exposed rats to other alkylating agents, namely nitromin and melphalan. The first agent induced the reduction of the spleen size without structural changes, while the second led to the atrophy of the white pulp.

In Doi et al. [32], upon rat exposure to cyclophosphamide, nitromin and melphalan, the red pulp of the spleen was not modified by cyclophosphamide but completely disappeared when the other two agents were used (not observed in the present study after exposure to the C. Oxyacantha extract).

The presence of proteins and polysaccharides in the spleen was detected through histochemical tests. The individuals in the control group presented positive results to the bromophenol blue test (for protein detection): the white pulp showed a weak to moderate positivity, the red pulp with blood vessels (splenic sinusoids) a moderate positivity and the splenic cords a strong positivity. In the PAS test, for neutral polysaccharides detection, the control group presented weak positivity in the white pulp and in the majority of the red pulp.

In the spleens from the individuals of the treatment groups, reactions similar to those found in the spleens from the control group mice were found, both in the bromophenol blue test and in the PAS test, demonstrating that the treatment with the different concentrations of the C. oxyacantha extract did not alter neither the constitution in protein nor polysaccharides of the spleen. Thus, it is perceived, through the results obtained by the exposure of mice to the extract of $C$. oxyacantha, that the spleen of the treated individuals did not present morphological or histochemical alterations and thus remains intact, performing its functions.

Schlegelmilch and Heywood [37] evaluated the toxicity of a standardized Crataegus extract (WS1442) in mice, rats and dogs. According to the authors, the extract did not cause toxicity at high doses and presented negative results in mutagenic and clastogenic tests. In Quadros et al. [13], the extractof $C$. oxyacantha fruits used in the present work showed genotoxic effects in cultured human peripheral blood lymphocytes and HepG2 cells. In the comet assay, primary DNA damage was detected, which may or may not be reversible but, in the micronuclei test, irreversible damage was observed, which demonstrated the genotoxic effects of $C$. oxyacantha extract at concentrations greater than $5 \mu \mathrm{g} / \mathrm{ml}$ [13].

According to the results of the histological and histochemical analyses obtained in the present study, evaluating the cytotoxicity of $C$. oxyacantha fruit extract in the liver and in the spleen of mice, it can be concluded that the higher doses of the extract led to cytoplasmic disorganization of liver cells (early stages), such as the presence of hepatocytes with more acidophiliccytoplasm, the formation of small vacuoles and intercellular spaces, increased lumen of the sinusoid capillaries and the increase of the liver tissue defense cells (Kupffer cells). No distinguishable morphological alterations were detected in the spleen cells. The hepatotoxicity observed in the present study, together with the recent genotoxic effects reported in the literature [13], indicate that the extract of $C$. oxyacantha fruits should be used with caution by the human population, avoiding the administration of high doses and/ 
Maistro et al., Journal of Histology \& Histopathology 2019, http://www.hoajonline.com/journals/pdf/2055-091X-6-10.pdf

or continuous use of it.

\section{Competing interests}

The authors declare that they have no competing interests.

\section{Authors' contributions}

\begin{tabular}{|l|c|c|c|c|c|c|c|}
\hline Authors' contributions & JCS & PRO & MICM & FFP & PCR & ELM & LOG \\
\hline Research concept and design & -- & -- & $\checkmark$ & -- & -- & $\checkmark$ & -- \\
\hline Collection and/or assembly of data & $\checkmark$ & $\checkmark$ & -- & -- & -- & -- & -- \\
\hline Data analysis and interpretation & $\checkmark$ & $\checkmark$ & $\checkmark$ & -- & -- & -- & -- \\
\hline Writing the article & $\checkmark$ & -- & -- & $\checkmark$ & $\checkmark$ & $\checkmark$ & -- \\
\hline Critical revision of the article & -- & -- & -- & -- & -- & $\checkmark$ & $\checkmark$ \\
\hline Final approval of article & -- & $\checkmark$ & $\checkmark$ & -- & -- & $\checkmark$ & -- \\
\hline Statistical analysis & $\checkmark$ & $\checkmark$ & -- & -- & -- & -- & -- \\
\hline
\end{tabular}

\section{Acknowledgments}

This work was supported by FAPESP (Fundação de Amparo à Pesquisa do Estado de São Paulo (Grant: 2014/26882-2)) and CNPq (Conselho Nacional de Desenvolvimento Científico e Tecnológico (Grant: 446232/2014-9). This work was partially funded by the project UID/CVT/00772/2019 supported by the Portuguese Science and Technology Foundation (FCT).

Publication history

Editor: Khin Thway, The Royal Marsden Hospital, UK.

Received: 07-Nov-2019 Final Revised: 08-Dec-2019

Accepted: 12-Dec-2019 Published: 18-Dec-2019

\section{References}

1. Alonso JR. "Tratado de fitomedicina - bases clínicas e farmacológicas". Editora Isis, 1998. Disponível em. Acesso em: 10 jan. 2017. I Pdf

2. Baker JR. The histochemical recognition of lipine. Q J Microsc Sci. 1946; 87:441-70. | Article | PubMed

3. Balbino $E E$ and Dias MF.Farmacovigilância: um passo em direção ao uso racional de plantas medicinais e fitoterápicos. RevBrasFarmacog. 2010; 20:6.

4. Balmer ML, Slack E, de Gottardi A, Lawson MA, Hapfelmeier S, Miele L, Grieco A, Van Vlierberghe H, Fahrner R, Patuto N, Bernsmeier C, Ronchi F, Wyss M, Stroka D, Dickgreber N, Heim MH, McCoy KD and Macpherson AJ. The liver may act as a firewall mediating mutualism between the host and its gut commensal microbiota. Sci Transl Med. 2014; 6:237ra66. | Article | PubMed

5. Cesta MF. Normal structure, function, and histology of the spleen. Toxicol Pathol. 2006; 34:455-65. | Article | PubMed

6. Cui T, Nakamura K, Tian S, Kayahara H and Tian YL. Polyphenolic content and physiological activities of Chinese hawthorn extracts. Biosci Biotechnol Biochem. 2006; 70:2948-56. | Article | PubMed

7. Doi T, Nagai H, Tsukuda R and Suzuki T. Dose-response relationships of cytotoxicity, PFC response and histology in the spleen in rats treated with alkylating agents. Toxicology. 1996; 107:47-60. | Article | PubMed

8. Ferreira M, De Oliveira PR, Denardi SE, Bechara GH and Mathias MI. Action of the chemical agent fipronil (active ingredient of acaricide Frontline(R)) on the liver of mice: an ultrastructural analysis. Microsc Res Tech. 2012; 75:197-205. | Article | PubMed

9. Garcia-Abiado MA, Mbahinzireki G, Rinchard J, Lee KJ and Dabrowski $K$. Effect of diets containing gossypol on blood parameters and spleen structure in tilapia, Oreochromis sp., reared in a recirculating system. $J$ Fish Dis. 2004; 27:359-68. | Article | PubMed

10. Gartner LP and Hiatt JL. Atlas colorido de histologia. $4^{\mathrm{a}}$ ed. Rio de Janeiro: Guanabara Koogan. 2007; 432.

11. Goldschneider I and McGregor DD. Anatomical distribution of T and B lymphocytes in the rat. Development of lymphocyte-specific antisera. J Exp Med. 1973; 138:1443-65. | Article | PubMed Abstract | PubMed
FullText

12. Greaves $P$ and Faccini JM. Haemopoietic and lymphatic systems. In: Rat Histopathology. A Glossary for Use in Toxicity and Carcinogenicity Studies. Amsterdam: Elsevier. 1992; 43-66.

13. Hamza RZ and Al-Harbi MS. Amelioration of paracetamol hepatotoxicity and oxidative stress on mice liver with silymarin and Nigella sativa extract supplements. Asian Pacific J Trop Biomed. 2015; 5:521-531.

14. Hosseinimehr SJ. Beneficial effects of natural products oncells during ionizing radiation. Rev EnvironHealth. 2014; 29:341-353.

15. Jenne $\mathrm{CN}$ and Kubes P. Immune surveillance by the liver. Nat Immunol. 2013; 14:996-1006. | Article | PubMed

16. Junqueira LCU and Junqueira LMMS. Técnicas básicas de citologia e histologia. São Paulo: Livraria Editora Santos. 1983; 48-81.

17. Junqueira LC and Carneiro J. Histologia Básica: Textos e Atlas. Rio de Janeiro: Guanabara Koogan, $12^{a}$ ed. 2013; 556.

18. Kierszenbaum AL. Histologia e Biologia celular: uma introdução à patologia. Rio de Janeiro: Elsevier. 2004; 310-501.

19. Kumararatne DS, Bazin $\mathrm{H}$ and MacLennan IC. Marginal zones: the major B cell compartment of rat spleens. Eur J Immunol. 1981; 11:858-64. | Article I PubMed

20. Lakshmi T, Geetha RV and Roy A. Crataegus oxyacantha Linn. Commonly known as Hawthorn - A scientific review. IntJ Pharm Tech Res. 2012; 4:458-465.

21. Lison L. Histochimie et Cytochimie Animales. Gauthier-Villars Éditeur, Paris. 1960.

22. Lora J. Avaliação da toxicidade aguda do extrato hidroalcoólico de folhas de Eugenia uniflora L. (Myrtaceae). Dissertação para obtenção do Título de Mestre em Ciências Ambientais. 59fls. Universidade do Extremo Sul Catarinense, Criciúma, SC, Brazil. 2007.

23. Nascimento DF, Santana APM, Leite IO, Viana FAC, Silva-Leite ALA, Moraes RA, Jamacaru FVF, Bezerra FAF, Moraes MO and Moraes MEA Estudo de toxicologia clínica de um fitoterápico contendo Passiflora incarnata L., Crataegus oxyacantha L., Salix alba L. em voluntários saudáveis. Rev. Bras. Farmacog. 2009; 19:1b.

24. De Oliveira PR, Bechara GH, Denardi SE, Oliveira RJ and Mathias MI. Cytotoxicity of fipronil on mice liver cells. Microsc Res Tech. 2012; 75:2835. | Article | PubMed

25. Oliveira AM, Nascimento MF, Ferreira MR, Moura DF, Souza TG, Silva GC, Ramos EH, Paiva PM, Medeiros PL, Silva TG, Soares LA, Chagas CA, Souza IA and Napoleao TH. Evaluation of acute toxicity, genotoxicity and inhibitory effect on acute inflammation of an ethanol extract of Morus alba L. (Moraceae) in mice. J Ethnopharmacol. 2016; 194:162-168. | Article | PubMed

26. Pearse AGE. Histochemistry: Theoretical and applied. London: Churchill. $1985 ; 530$.

27. Pereira-Bittencourt M, Carvalho DD, Gagliardi AR and Collins DC. The effect of a lectin from the venom of the snake, Bothrops jararacussu, on tumor cell proliferation. Anticancer Res. 1999; 19:4023-5. | PubMed

28. de Quadros APO, Mazzeo DEC, Marin-Morales MA, Perazzo FF, Rosa PCP and Maistro EL. Fruit extract of the medicinal plant Crataegus oxyacantha exerts genotoxic and mutagenic effects in cultured cells. $J$ Toxicol Environ Health A. 2017; 80:161-170. | Article | PubMed

29. Rigelsky JM and Sweet BV. Hawthorn: pharmacology and therapeutic uses. Am J Health Syst Pharm. 2002; 59:417-22. | Article | PubMed

30. Roma GC, De Oliveira PR, Bechara GH and Camargo Mathias MI. Cytotoxic effects of permethrin on mouse liver and spleen cells. Microsc Res Tech. 2012; 75:229-38. | Article | PubMed

31. Ross MH and Pawlina W. Histologia em correlação com biologia celular e molecular. Rio de Janeiro: Guanabara Koogan. 2008; 427-594.

32. Salam OME, Sleem AA and Shafee N. Hepatoprotective effects of Cynara extract and silymarin on carbon tetrachloride-induced hepatic damage in rats. Comp Clin Path. 2014; 23:709-716.

33. Schlegelmilch R and Heywood R. Toxicity of Crataegus (hawthorn) extract (WS1442). JAmCollToxicol. 1994; 13:103-111.

34. Tadic VM, Dobric S, Markovic GM, Dordevic SM, Arsic IA, Menkovic 
Maistro et al., Journal of Histology \& Histopathology 2019,

http://www.hoajonline.com/journals/pdf/2055-091X-6-10.pdf

NR and Stevic T. Anti-inflammatory, gastroprotective, free-radicalscavenging, and antimicrobial activities of hawthorn berries ethanol extract. J Agric Food Chem. 2008; 56:7700-9. | Article | PubMed

35. Teh SJ, Adams SM and Hinton DE. Histopathological biomarkers in feral freshwater fish populations exposed to different types of contaminant stress. Aquat Toxicol. 1997; 37:51-70.

36. Tomazzoni MI, Negrelle RRB and Centa ML. Fitoterapia popular: a busca instrumental enquanto prática terapeuta. Texto \& Contexto Enfermagem. 2006; 15:115-121.

37. Weihmayr T and Ernst E. [Therapeutic effectiveness of Crataegus]. Fortschr Med. 1996; 114:27-9. | PubMed

\section{Citation:}

dos Santos JC, de Oliveira PR, Camargo-Mathias MI, Perazzo FF, Rosa PCP, Gaivão IOM and Maistro EL.

Hepatic and splenic cytotoxic evaluation after Crataegus oxyacantha fruit extract administration on mice. J Histol Histopathol. 2019; 6:10.

http://dx.doi.org/10.7243/2055-091X-6-10 